\title{
Estabelecimento de um protocolo de Nested-PCR para detecção do vírus da anemia das galinhas e análise filogenética de cepas brasileiras*
}

\author{
SIMONE SIMIONATTO
}

\author{
Cláudio Wageck Canal (Orientador - UFRGS) \\ Carlos André da Veiga Lima-Rosa (Co-orientador - UFRGS)
}

Banca: Gertrudes Corção (UFRGS), Odir Antônio Dellagostin (UFPel), Paulo Michel Roehe (UFRGS)

$\mathrm{O}$ vírus da anemia das galinhas (CAV) pode causar imunodepressão em galinhas de todas as idades e doença nos frangos jovens, a qual é caracterizada por severa anemia, atrofia da medula óssea e hemorragias. A doença clínica é rara hoje, porém a forma subclínica é, freqüentemente, encontrada em criações comerciais e resulta num considerável decréscimo do desempenho. O CAV apresenta variabilidade genética, entretanto, em relação às amostras brasileiras do CAV, pouco ou quase nada desta variabilidade é conhecida. O presente trabalho descreve um protocolo de Nested-PCR para a detecção do CAV diretamente de amostras clínicas e analisa filogeneticamente as seqüências nucleotídicas das amostras positivas buscando verificar se a patologia apresentada por estas está relacionada com a variabilidade genética. Para a extração de DNA, o método baseado em tiocianato de guanidina mostrou-se mais eficiente e prático de executar que os demais testados. Foi selecionado um par de primers que amplifica uma região de 664 pb do gene vpl e outro par que amplifica uma região interna de 539 pb para a realização da Nested-PCR. A especificidade dos primers foi avaliada utilizando amostras de lotes controlados para CAV e 30 diferentes isolados de vírus e bactérias causadoras de doenças em galinhas, as quais não geraram produto de amplificação. A sensibilidade foi determinada a partir de diluições seriadas da vacina comercial para o CAV. A Nested-PCR mostrou ser mais sensível do que a PCR e foi capaz de detectar $0,16 \mathrm{DICC}_{50 \%}$ da cepa vacinal. Além disso, a Nested-PCR detectou DNA viral em tecidos, soro e cama aviária de lotes com e sem sintomas clínicos. O produto de amplificação de 539 pb do gene $v p l$ de 44 amostras, provenientes de diferentes Estados produtores de frangos do Brasil, foi seqüenciado e foram encontradas 10 novas seqüências nucleotídicas do CAV. Estas 10 seqüências nucleotídicas foram analisadas filogeneticamente pelo método de distância neighbour joining com 1000 replicações o qual, mostrou que não houve correlação entre a patogenia apresentada nos animais e os grupos genéticos. Estas seqüências nucleotídicas também foram comparadas com 30 cepas de CAV isoladas em outros países e não foi observada correlação entre a distribuição geográfica e a variabilidade genética. Substituições de amino ácidos foram observadas em 9 posições sendo que, ${ }^{65} \mathrm{R}$ substituindo o resíduo $\mathrm{Q} e{ }^{98} \mathrm{~F}$ substituindo o resíduo $\mathrm{Y}$ ainda não haviam sido observadas. Conclui-se que, como técnica de detecção do CAV, o protocolo de Nested-PCR aqui descrito é mais sensível e menos trabalhoso do que o isolamento viral. As amostras Brasileiras de CAV possuem características filogenéticas similares às isoladas em outros países.

Descritores: vírus da anemia das galinhas (CAV), patologia aviária, virologia, diagnóstico molecular, Nested-PCR, análise filogenética. 


\title{
Establishment of a nested-PCR protocol for detection of chicken anemia virus and phylogenetic analysis of Brazilian strains ${ }^{* *}$
}

\author{
SIMONE SIMIONATTO
}

Cláudio Wageck Canal (Adviser - UFRGS)

Carlos André da Veiga Lima-Rosa (Co-Adviser - UFRGS)

Commitee: Gertrudes Corção (UFRGS), Odir Antônio Dellagostin (UFPel), Paulo Michel Roehe (UFRGS)

Chicken anemia virus (CAV) can cause immunosuppression in all birds and a disease in young chickens, characterized by severe anemia, bone marrow atrophy and hemorrhages. The clinical disease is rare today, but the subclinal form is frequently found in commercial flocks and result in measurably decreased performance. The genetic variability among the CAV was reported, but little is know about the Brazilian CAV samples. The present work reports a Nested-PCR protocol for detection of CAV directly from clinical specimen. A phylogenic analysis of the nucleotide sequence obtained from the positive samples was carried out in order to evaluate if there was any relationship between the pathology of these samples and the genetic variability. For DNA extraction, a method based on guanidine thiocyanate was found more sensitive and practical than the other extraction protocols tested. The initial pair of primers used in the PCR assay targeted a $664 \mathrm{bp}$ fragment on the vp1 gene. The primers for the Nested-PCR assay targeted an internal fragment of $539 \mathrm{bp}$. The specificity of the primers was evaluated with samples of CAV from controlled flocks and 30 different viruses and bacteria isolated from chickens and those did not give rise to any amplification product. The sensitivity of the Nested-PCR was determined on serial dilutions of a CAV comercial vaccine. The Nested-PCR assay showed to be more sensitive than a one step PCR assay and was able to detect 0.16 TCID $_{50 \%}$ of the vaccine strain. In addition, the protocol employed here detected viral DNA from tissues, sera and litter from flocks with or without clinical symptoms. The 539 bp of vp1 gene amplification products from the 44 field samples, deriving from different Brazilian geografic regions were sequenced and 10 new nucleotide sequences of CAV were found. These were analysed phylogenetic using maximum neighbourjoining distance methods, with 1000 bootstrap replications and did not show correlations between CAV pathology pattern and genetic groups. Also, these sequences were analysed together with $30 \mathrm{CAV}$ sequences isolated in other countries and it was not observed correlation between geographical distribuition and genetic variability. Amino acid substitutions were detected at 9 positions of the Brazilian sequences and two of them were not observed before, ${ }^{65} \mathrm{R}$ replacing the Q residue and ${ }^{98} \mathrm{~F}$ replacing Y residue. It is concluded that the Nested-PCR protocol described here is more sensitive and less cumbersome than virus isolation as a diagnostic technique for detection of CAV. Brazilian samples had similar phylogenetic characteristics to CAV isolated elsewhere.

Key words: chicken anemia virus (CAV); avian pathology; virology; molecular diagnosis; Nested-PCR; phylogenetic analysis. 